\title{
PERSEPSI DAN PERILAKU MASYARAKAT SEKITAR HUTAN MANGROVE TERHADAP PELESTARIAN MANGROVE DI KAWASAN TAMAN HUTAN RAYA NGURAH RAI BALI
}

\author{
Catarina Tenny Setiastri $^{\left.1^{*}\right)}$, I Wayan Windia ${ }^{2)}$, Ida Ayu Astarini ${ }^{3)}$ \\ ${ }^{1)}$ Program Studi Magister Ilmu Lingkungan, Universitas Udayana \\ ${ }^{2)}$ Program Studi Agribisnis, Fakultas Pertanian, Universitas Udayana \\ ${ }^{3)}$ Program Studi Biologi, FMIPA, Universitas Udayana \\ *Email: tenny.setiastri@gmail.com
}

\section{ABSTRACT \\ LOCAL COMMUNITY'S PERCEPTION AND THEIR BEHAVIOR OF MANGROVE PRESERVATION IN NGURAH RAI FOREST PARK BALI}

\begin{abstract}
Ngurah Rai Forest Park Bali isa mangrove conservation which covers 1,373.50 ha; the largest mangrove forestarea in Bali. However, its strategic location, in the center of business and the golden triangle of tourism (Sanur, Nusa Dua, and Kuta), creates pressures from various interests. This threat causes 253.40 ha of mangrove forest area in Ngurah Rai Forest Park Baliseverely damaged. The aims of this studywere: (1) to analyze the forms of land function change occurred in Ngurah Rai Forest Park Bali; (2) to analyze perception of the community around Ngurah Rai Forest Park Bali about mangrove conservation; (3) to analyze the behavior of the community around Ngurah Rai Forest Park Bali about mangrove conservation. The research was conducted fromMay until July 2018 in Tuban and Pedungan District.This study uses 2 (two) analytical methods, 1)literature study methods, to determine the form of land function change that occurred in the Ngurah Rai Area of Bali, 2)categorical quantitative analysis method to determine the perceptions and behavior of the local community.The categorical quantitative analysis method was used to categorize the perceptions and behaviors of local people. It is qualified into 4 (four) categories on a Likert scale. The results of the questionnaire collected were categorized into 4 (four) levels and discussed descriptively. This paper was based on primary data taken using questionnaire with a predetermined analysis unit to interview the community in the study area. The result presented with quantitative and descriptive analysis. The result shows that within twelve years, from 2000 to 2012, Ngurah Rai Forest Park Bali has a land function change of 29.76 ha or $2.16 \%$; from $1,161.76$ ha in 2000 to $1,132.00$ ha in 2012 . The level of community perception towards the mangrovepreservation of Ngurah Rai Forest Park Baliis very good but the level of its community behavior is bad. It can concluded that good perception do not always have a good impact of people behavior towards the mangrove conservation.
\end{abstract}

Keywords: mangrove, perception, behavior, conservation

\section{PENDAHULUAN}

Hutan mangrove di Indonesia mengalami tingkat kerusakan yang tinggi. Selama tiga dekade terakhir, Indonesia kehilangan $40 \%$ hutan mangrove (FAO, 2007), yang merupakan kerusakan tercepat di dunia (Campbell dan Brown, 2015).Hutan mangrove beralih fungsi menjadi tambak, tergerus perluasan lahan pertanian, tergerus pesatnya pembangunan pariwisata, dan pembangunan perkotaan (Susilo, 1997). Tingkat kerusakan mangrove yang tinggi ini merusak ekosistem pesisir, menurunkan kualitas dan jumlah ikan dan biota lain, mengurangi estetika lingkungan, menghilangkan tiga fungsi mangrove, yaitu fungsi ekologis, fungsi fisik, dan fungsiekonomis (Setiawan, 2013), serta menghilangkan perannya dalam mengakumulasi dan mengurangi toksisitas logam berat di wilayah perairan (Supriyantini dkk., 2017). 
Kawasan Taman Hutan Raya Ngurah Rai Bali merupakan kawasan konservasi mangrove seluas 1.373,50 Ha (Keputusan Kehutanan No 554/Ktps-II/1993 tanggal 25 September 1993), yang berada di dua wilayah: Kota Denpasar seluas 734,50 ha dan Kabupaten Badung seluas 639 ha (Balai Lingkungan Hidup Kota Denpasar, 2017). Kawasan ini merupakan luasan mangrove terbesar, yaitu $63,1 \%$ dari total hutan mangrove di Bali. Namun, lokasi Kawasan Tahura Ngurah Rai Bali yang strategis, di pusat bisnis dan segitiga emas pariwisata (Sanur, Nusa Dua, dan Kuta), menimbulkan tekanan-tekanan dari berbagai kepentingan (Pradnyana dkk., 2015).

Ancaman serius muncul saat persepsi masyarakat yang menganggap mangrove sebagai sumberdaya yang kurang berguna, yang hanya cocok untuk tempat pembuangan sampah atau dikonversi untuk keperluan lain yang lebih berguna bagi individu, perusahaan, dan pemerintah (Buwono dkk, 2014). Perusakan dan ketidaktahuan akan fungsi mangrove menyebabkan kerusakan bertambah parah (Subhan, 2014). Di sisi lain, Peraturan Pemerintah pun memiliki andil dalam pengembangan Kawasan Tahura Ngurah Rai. Peraturan Presiden Republik Indonesia Nomor 51 Tahun 2014 tentang Tata Ruang Perkotaan Denpasar, Badung, Gianyar, dan Tabanan, mengubah status hutan mangrove dari hutan lindung menjadi kawasan budidaya. Luas vegetasi hutan mangrove pun mengalami penurunan karena banyaknya alih fungsi lahan hutan menjadi lahan pertanian, akuakultur, pariwisata, dan pembangunan perkotaan (UPT Tahura Ngurah Rai, 2017). Kegiatan alih fungsi ini diperparah dengan pencemaran sampah-sampah residu bahan kimia yang dibawa aliran sungai (Bali Post, 26 April 2017) dan pembangunan jalan tol Bali Mandara. Underpass Simpang Tugu Ngurah Rai dengan panjang total 712 meter dan lebar 16 meter pun mengambil 34 are luas wilayah hutan Tahura dan pembatatan sekitar 750 pohon mangrove (Tiga Pilar News, 23 Desember 2017).Ancaman ini menyebabkan 253,40 ha luas hutan mangrove di Kawasan Tahura Ngurah Rai Bali rusak parah (Lugina dkk., 2017).
Berdasarkan pertimbangan pentingnya manfaat mangrove di Kawasan Tahura Ngurah Rai Bali, yang akan berdampak pada pulau Bali serta masyarakat, khususnya masyarakat pesisir yang tinggal di sekitar mangrove, maka diperlukan kajian tentang bentuk alih fungsi lahan yang terjadi serta kajian tentang persepsi dan perilaku masyarakat sekitar mangrove terhadap pelestarian mangrove yang ada. Bila persepsi dan perilaku masyarakat sekitar mangrove baik dan positif terhadap pelestarian mangrove, maka ini akan menjadi sumbangan positif terhadap pelestarian lingkungan pada umumnya dan pelestarian mangrove di Kawasan Tahura Ngurah rai Bali pada khususnya. Tujuan penelitian ini adalah untuk menganalisis bentuk alih fungsi lahan yang terjadi di Kawasan Tahura Ngurah Rai Bali, mengetahui persepsi dan perilaku masyarakat sekitar hutan mangrove terhadap pelestarian mangrove di Kawasan Tahura Ngurah Rai Bali.

\section{METODOLOGI}

\subsection{Waktu dan Lokasi Penelitian}

Penelitian ini dilaksanakan pada bulan Mei hingga Juli 2018. Lokasi penelitian di sepanjang pinggiran hutan mangrove Kelurahan Pedungan dan di sepanjang pinggiran hutan mangrove Desa Tuban, di Kawasan Tahura Ngurah Rai Bali, di sebelah timur Jalan Bypass Ngurah Rai.

\subsection{Jenis dan Sumber Data}

Jenis data adalah kuantitatif dan kualitatif. Data kuantitatif dipaparkan dalam bentuk angka-angka dari sumber-sumber pustaka, antara lain jurnal, tesis, dan informasi dari masing-masing desa, diantaranya: angkaangka luasan Kawasan Tahura Ngurah Rai Bali. Data kualitatif diperoleh dari jawaban para responden dan narasumber.

Sumber data diperoleh dari data primer dan data sekunder. Data primer berupa kuesioner semi tertutup dan observasi langsung. Data sekunder berupa dokumentasi untuk mendapatkan gambaran kondisi masyarakat Kelurahan Pedungan dan Desa Tuban dalam bidang sosial dan ekonomi dan bentuk alih fungsi lahan yang terjadi di Kawasan Tahura Ngurah Rai Bali. 
Tabel 1. Pengelompokkan Jenis Sumber Data yang Dianalisis dalam Penelitian

\begin{tabular}{llll}
\hline Jenis Data & \multicolumn{1}{c}{ Instrumen } & \multicolumn{1}{c}{ Sumber } & \multicolumn{1}{c}{ Parameter } \\
\hline Data primer & Kuesioner semi tertutup Responden & $\begin{array}{l}\text { Persepsi dan perilaku masyarakat } \\
\text { sekitar mangrove }\end{array}$ \\
& Observasi langsung & Lapangan & Mengetahui jenis mangrove \\
& Observasi langsung & Lapangan & Mengetahui lingkungan mangrove \\
$\begin{array}{l}\text { Data } \\
\text { sekunder }\end{array}$ & $\begin{array}{l}\text { Dokumentasi } \\
\text { Kepustakaan }\end{array}$ & $\begin{array}{l}\text { Monografi desa } \\
\text { Jurnal }\end{array}$ & $\begin{array}{l}\text { Gambaran kondisi masyarakat } \\
\text { Kelurahan Pedungan dan Desa Tuban } \\
\text { Bentuk konversi yang terjadi }\end{array}$ \\
\hline
\end{tabular}

\subsection{Populasi dan Sampel}

Populasi dalam penelitian ini adalah semua keluarga di Kelurahan Pedungan dan Desa Tuban yang menetap di pinggir hutan mangrove di Kawasan Tahura Ngurah Rai, di sebelah timur Jalan Bypass Ngurah Rai. Penentuan populasi dilakukan dengan pertimbangan jarak tempat tinggal masyarakat yang dekat dengan hutan mangrove.

Sampel dalam penelitian ini adalah bagian populasi yang berperan sebagai responden. Penentuan sampel melalui metode accidental sampling, yaitu semua kepala keluarga yang ditemui saat penyebaran kuesioner dan wawancara, sejumlah 44 kepala keluarga. Jumlah sampel sebanyak $30-60$ orang atau 120 - 150 orang dianggap efektif secara penuh dalam statistik (Champion, 1981). Untuk memperkaya data penelitian, diwawancarai pula beberapa tokoh masyarakat sebagai informan kunci, yaitu staff UPT Tahura, staff KLKH Direktorat Jendral Pengendalian Iklim, kelian, pemuka adat, sekretaris kelompok nelayan, dan ketua kelompok tani mangrove.

\subsection{Instrumen Penelitian}

Instrumen yang dipakai adalah panduan wawancara, kuesioner, peralatan dokumentasi, peta dan Global Positioning System (GPS).

\subsection{Teknik Pengumpulan Data}

Untuk mendapatkan tujuan persepsi dan perilaku masyarakat, teknik yang digunakan dalam penelitian ini adalah teknik wawancara semi tertutup yaitu dengan penyebaran kuisioner, serta teknik observasi untuk mengecek data yang diperoleh dari sampel tentang kejadian yang sebenarnya di lapangan. Studi dokumen yang merupakan media perekaman terhadap proses dan fenomena sosial digunakan untuk menjawab tujuan pertama, yaitu: bentuk alih fungsi lahan yang terjadi di Kawasan Tahura Ngurah Rai Bali.

\subsection{Analisa Data}

Penelitian ini menggunakan 2 (dua) metode analisis, yaitu metode studi kepustakaan, seperti: literatur, tulisan, hasil penelitian, koran, dan lainnya untuk mengetahui bentuk alih fungsi lahan yang terjadi di Kawasan Tahura Ngurah Rai Bali dan metode analisis kuantitatif kategorik untuk mengetahui persepsi dan perilaku masyarakat setempat. Metode analisis kualitatif kategorik mengkategorikan persepsi dan perilaku responden masyarakat setempat yang bersifat kualitatif menjadi lima kategori dengan skala Likert. Setelah itu, hasil kuesioner yang terkumpul dikategorikan menjadi 4 (empat) tingkatan dan dibahas secara deskriptif kuantitatif yang selanjutnya dikualitatifkan, dengan tujuan menyajikan, mendeskripsikan, menguraikan, dan menjelaskan secara sistematis. Untuk keperluan analisis kuantitatif, maka jawaban diberi bobot nilai sebagai berikut: tidak setuju diberi bobot nilai 1, kurang setuju diberi bobot nilai 2, setuju diberi bobot nilai 3, dan sangat setuju diberi bobot nilai 4 .

Setelah merangkum semua bobot nilai persepsi, dihitung dengan mengalikan jumlah responden dengan bobot sehingga menghasilkan skor rata-rata atau nilai dari 
masing-masing persepsi sesuai tujuan penelitian. Skor rata-rata atau nilai berupa angka ini kemudian diinterpretasikan sesuai kategori nilai. Berikut cara perolehan interval kelas untuk mendapatkan kisaran skor:

$$
\begin{aligned}
\text { Interval kelas } & =\frac{\text { skor tertinggi }- \text { skor terendah }}{\text { jumlah kelas }} \\
& =\frac{4-1}{4}=\frac{3}{4}=0.75
\end{aligned}
$$

Kategori nilai persepsi dan perilaku masyarakat setempat dituangkan pada Tabel 2.

Tabel 2. Skoring Persepsi dan Perilaku Masyarakat Setempat Berdasarkan Skala Likert

\begin{tabular}{ccl}
\hline No & Kisaran Skor & Keterangan \\
\hline 1 & $1,00-<1,75$ & Sangat buruk \\
2 & $1,76-<2,50$ & Buruk \\
3 & $2,51-<3,25$ & Baik \\
4 & $3,26-<4,00$ & Sangat baik \\
\hline
\end{tabular}

Kebijakan pemerintah pusat dan pemerintah daerah dianalisis secara deskriptif kualitatif dengan tujuan menggambarkan dan menguraikan kebijakan yang berpengaruh terhadap pengelolaan mangrove di Kawasan Tahura Ngurah Rai Bali. Adapun aspek persepsi dan perilaku yang dianalisis meliputi fungsi atau manfaat mangrove yang dirasakan oleh masyarakat, keterlibatan dan peran masyarakat dalam pengelolaan mangrove, penegakan hukum baik hukum negara maupun hukum adat, kegiatan yang dapat dikembangkan di sekitar kawasan mangrove, serta model pengelolaan mangrove yang diharapkan masyarakat.

\section{HASIL DAN PEMBAHASAN}

\subsection{Bentuk Alih Fungsi Lahan di Kawasan Tahura Ngurah Rai Bali}

Kawasan Taman Hutan Raya Ngurah Rai Bali merupakan salah satu kawasan konservasi mangrove yang ada di Bali, yang memiliki luas 1.373,50 ha (Keputusan Menteri Kehutanan No 554/Ktps-II/1993 tanggal 25 September 1993). Letak geografis kawasan ini adalah $08^{\circ} 41^{\prime}-08^{\circ} 47^{\prime}$ LS dan $115^{\circ} 10^{\prime}-115^{\circ} 15$ BT. Secara administrasi pemerintah, kawasan ini berada di 2 (dua) wilayah: Kota Denpasar seluas 734,50 ha dan Kabupaten Badung seluas 639 ha (Balai Lingkungan Hidup Kota Denpasar, 2017).

Kawasan Taman Hutan Raya Ngurah Rai di Kota Denpasar meliputi Kecamatan Denpasar Selatan (Desa Pemogan, Pedungan, Sesetan, Serangan, Sidakarya, dan Sanur Kauh) sedangkan di Kabupaten Badung meliputi Kecamatan Kuta Selatan (Desa Benoa, Tanjung Benoa, Tuban, dan Kuta). Batas-batas Kawasan Tahura Ngurah Rai Bali (BPKH wilayah VIII Denpasar), sebagai berikut: di sebelah utara berbatasan dengan Kota Denpasar dan Kabupaten Badung, di sebelah timur berbatasan dengan Selat Penida, di sebelah selatan berbatasan dengan Samudera Indonesia, dan di sebelah barat berbatasan dengan Kabupaten Badung.

Kawasan Taman Hutan Raya Ngurah Rai memiliki kondisi mangrove yang relatif baik dibandingkan dengan daerah lain di sekitarnya. Kondisi ini dibuktikan dengan diidentifikasinya beraneka jenis mangrove, yang sesuai dengan identifikasi Kitamura, dkk (1997), yaitu mangrove sejati dan mangrove asosiasi, 17 famili, dan 24 spesies. Di tahun 2014, Hamiudin mengidentifikasi 21 mangrove sejati dan 26 spesies mangrove asosiasi; spesies mangrove yang dominan adalah Sonneratia alba.Identifikasi mangrove di Kawasan Taman Hutan Raya Ngurah Rai tahun 2018 dipaparkan pada Tabel 3 
Tabel 3. Jenis Spesies Mangrove Kawasan Taman Hutan Raya Ngurah Rai. 2018

\begin{tabular}{|c|c|c|c|c|c|}
\hline No & Status & Famili & Spesies & Nama Lokal & Lokasi \\
\hline 1 & Sejati & Rhizophoraceae & Bruguiera gymnorrhiza (L.) Lam. & Lindur & $\mathrm{T}$ \\
\hline 2 & & & Ceriops tagal C. B. Rob. & Lindur & $\mathrm{T}$ \\
\hline 3 & & & Rhizophora apiculata Blume & Jangkah & $\mathrm{T}, \mathrm{P}$ \\
\hline 4 & & & Rhizophora stylosa Griff. & Bakau & $\mathrm{T}$ \\
\hline 5 & & & Rhizophora mucronata Lam. & Bakau & $\mathrm{T}, \mathrm{P}$ \\
\hline 6 & & Sonneratiaceae & Sonneratia alba J. Sm. & Prapat & $\mathrm{T}, \mathrm{P}$ \\
\hline 7 & & & Sonneratia caseolaris (L.) Engl. & Pidada & $\mathrm{T}$ \\
\hline 8 & & Meliaceae & Xylocarpus granatum Koen. & Banang-banang & $\mathrm{T}$ \\
\hline 9 & & & $\begin{array}{l}\text { Xylocarpus moluccensis (Lam.) M. } \\
\text { Roem }\end{array}$ & Banang-banang & $\mathrm{T}$ \\
\hline 10 & & Palmae & Nypa fruticans Wurmb & Buyuk & $\mathrm{T}$ \\
\hline 11 & & Lythraceae & Pemphis acidula J.R. Forst. \& G. Forst. & Sentigi & $\mathrm{T}$ \\
\hline 12 & & Avicenniaceae & Avicennia marina (Forssk.) Vierh. & Api-api & $\mathrm{P}$ \\
\hline 13 & Asosiasi & Acanthaceae & Acanthus ilicifolius $\mathrm{L}$. & Jeruju & $\mathrm{T}$ \\
\hline 14 & & Guttiferae & Calophyllum inophyllum L. & Camplung & $\mathrm{T}$ \\
\hline 15 & & Verbenaceae & Clerodendrum inerme Gaertn. & Kayu Tulang & $\mathrm{T}, \mathrm{P}$ \\
\hline 16 & & Leguminosae & Derris trifoliate Lour. & Ambung & $\mathrm{T}$ \\
\hline 17 & & Asclepiadaceae & $\begin{array}{l}\text { Finlaysonia maritime Backer ex K. } \\
\text { Heyne }\end{array}$ & Tebel-tebel & $\mathrm{T}$ \\
\hline 18 & & Malvaceae & Hibiscus tiliaceus L. & Waru Lot & $\mathrm{T}$ \\
\hline 19 & & & Thespesia populnea (L.) Sol. Ex Correa & Waru Lot & $\mathrm{T}$ \\
\hline 20 & & Convolvulaceae & Ipomoea pes-caprae (L.) Sweet & Katang-katang & $\mathrm{T}$ \\
\hline 21 & & Pandanaceae & Pandanus tectorius Parkinson. & Pandan & $\mathrm{T}$ \\
\hline 22 & & Leguminosae & Pongamia pinnata (L.) Pierre & Kwanji & $\mathrm{T}$ \\
\hline 23 & & Aizoaceae & Sesuvium portulacastrum (L.) L. & Sesepi & $\mathrm{T}, \mathrm{P}$ \\
\hline 24 & & Combretaceae & Terminalia catappa $\mathrm{L}$. & Ketapang & $\mathrm{T}$ \\
\hline
\end{tabular}

Keterangan: $\mathrm{T}=$ Desa Tuban, $\mathrm{P}=$ Kelurahan Pedungan

Selain manfaat ekologi, kondisi hutan mangrove yang baik di Kawasan Taman Hutan Raya Ngurah Rai juga memberi manfaat ekonomi bagi masyarakat di sekitarnya. Kegiatan ekonomi mangrove yang beragam seperti dalam Poklahsar (Pengolahan dan Pemasaran Wanasari) berhasil mengkaryakan 96 istri-istri para nelayanDesa Tuban hingga menjadi berpenghasilan. Penghasilan ini sangat membantu perekonomian keluarga. Kegiatan ekonomis mangrove Poklahsar yang dikemas dengan program ekowisata ini ditampilkan pada Tabel 4.

Tabel 4. Kegiatan Ekonomis Olahan Mangrove di Desa Tuban

\begin{tabular}{|c|c|c|c|}
\hline No & Jenis Kegiatan Ekonomi & Hasil Olahan & Nilai Ekonomis \\
\hline \multirow[t]{3}{*}{1} & Pengolahan ikan dan kepiting & Ikan Kerapu & Rp 85.000 /ekor \\
\hline & & Kepiting & Rp 125.000 /ekor \\
\hline & & Kerang bakau & Rp 60.000 /ekor \\
\hline \multirow[t]{3}{*}{2} & Pengolahan buah pidada & Jus mangrove & $\mathrm{Rp} 30.000 / 330 \mathrm{ml}$ \\
\hline & & Selai mangrove & Rp $20.000 / 150$ gram \\
\hline & & Isian coklat & $\mathrm{Rp} 20.000 / \mathrm{pak}$ \\
\hline 3 & Pengolahan buah lindur & Kripik & Rp 25.000 /bungkus \\
\hline 4 & Pengolahan buah banang-banang & Serbuk lulur & Rp $20.000 / 50$ gram \\
\hline 5 & Ekowisata & Kelas memasak & Rp150.000 /orang/ jam \\
\hline 6 & Penjualan bibit mangrove & Bibit & Rp $15.000 /$ bibit \\
\hline
\end{tabular}

Sumber: Kadek Surasmini. Ketua Pohlaksar Wanasari. 2018 
Luas hutan mangrove di Kawasan Tahura Ngurah Rai Bali mencakup 1.373,50 ha (KepMenHut/Nomor 554/KTPS-II/1993 tanggal 25 September 1993), sekitar 1,1\% dari total luas hutan Provinsi Bali yang mencapai 130.868,10 ha (UPT Tahura Ngurah Rai, 2017). Namun lokasi Kawasan Tahura Ngurah Rai Bali yang strategis, di pusat bisnis dan segitiga emas pariwisata Sanur, Nusa Dua, dan Kuta, menimbulkan banyak tekanan dari berbagai kepentingan (Pradnyana dkk., 2015).Tantangan perlindungan dan pengelolaan hutan di Indonesia seringkali justru datang dari masyarakat sekitar hutan. Padahal kelestarian pengelolaan hutan sangat tergantung pada partisipasi masyarakat lokal (Laksmi dkk., 2013). Ini dibuktikan dengan adanya alih fungsi lahan hutan mangrove sebesar 10,6 ha di Kawasan Tahura Ngurah Rai Bali pada tahun 2010. Alih fungsi lahan hutan mangrove ini disebabkan oleh bertambahnya luas pemukiman seluas 0,37 ha, luas lahan terbuka sebesar 3,71 ha, bertambahnya luas tubuh air sebesar 6,27 ha, dan bertambahnya luas tambak sebesar 0,25 ha. Di tahun ini, bertambahnya luas tutupan tubuh air merupakan faktor pertambahan luas terbesar yang mengakibatkan alih fungsi lahan hutan mangrove di Kawasan Tahura Ngurah Rai Bali.

Menurut Balai Pemantapan Kawasan Hutan (2018), dalam kurun waktu 12 tahun (2000 - 2012), luas hutan mangrove di Kawasan Tahura Ngurah Rai Bali mengalami alih fungsi lahan sebesar 29,76 ha karena merebaknya pembukaan tambak. Bentuk alih fungsi lahan di Kawasan Tahura Ngurah Rai Bali adalah pemukiman, lahan terbuka, tubuh air, dan tambak. Bentuk alih fungsi lahan hutan mangrove di Kawasan Tahura Ngurah Rai Bali dipaparkan pada Tabel 5 dan Gambar 1.

Tabel 5.Alih Fungsi Lahan Mangrove di Kawasan Tahura Ngurah RaiTahun 2000-2012

\begin{tabular}{llrrrrrrr}
\hline No & Penutupan Lahan & \multicolumn{7}{c}{ Luasan Tutupan (ha) } \\
\cline { 3 - 8 } & & \multicolumn{1}{c}{2000} & \multicolumn{1}{c}{2002} & \multicolumn{1}{c}{2004} & \multicolumn{1}{c}{2006} & \multicolumn{1}{c}{2008} & \multicolumn{1}{c}{2010} & \multicolumn{1}{c}{2012} \\
\hline 1 & Hutan mangrove & $1.161,76$ & $1.161,76$ & $1.160,95$ & $1.160,95$ & $1.148,38$ & $1.137,78$ & $1.132,00$ \\
2 & Pemukiman & 11,15 & 11,15 & 11,15 & 11,15 & 11,97 & 12,34 & 16,27 \\
3 & Lahan terbuka & 41,93 & 41,93 & 41,93 & 41,93 & 43,79 & 47,50 & 49,35 \\
4 & Tubuh air & 137,75 & 137,75 & 137,75 & 137,75 & 137,74 & 144,01 & 144,01 \\
5 & Tambak & 20,91 & 20,91 & 21,72 & 21,72 & 31,62 & 31,87 & 31,87 \\
\hline Jumlah & $\mathbf{1 . 3 7 3 , 5 0}$ & $\mathbf{1 . 3 7 3 , 5 0}$ & $\mathbf{1 . 3 7 3 , 5 0}$ & $\mathbf{1 . 3 7 3 , 5 0}$ & $\mathbf{1 . 3 7 3 , 5 0}$ & $\mathbf{1 . 3 7 3 , 5 0}$ & $\mathbf{1 . 3 7 3 , 5 0}$ \\
\hline
\end{tabular}

Sumber: Balai Pemantapan Kawasan Hutan. 2018.

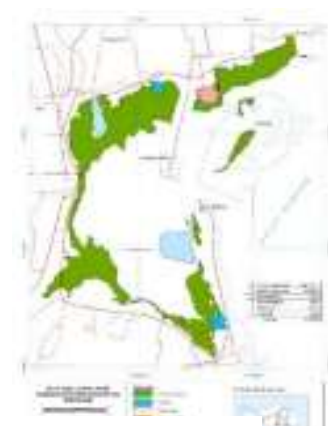

Tahun 2000

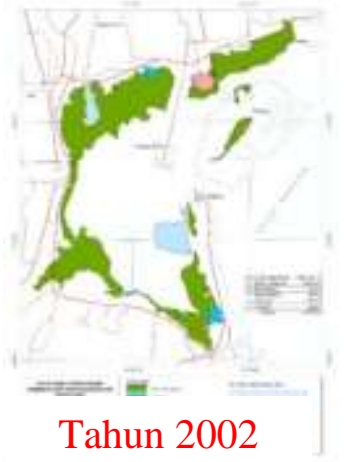

Tahun 2002

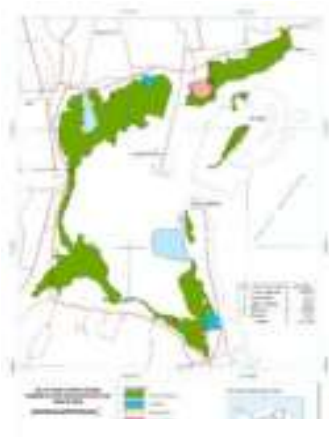

Tahun 2004 


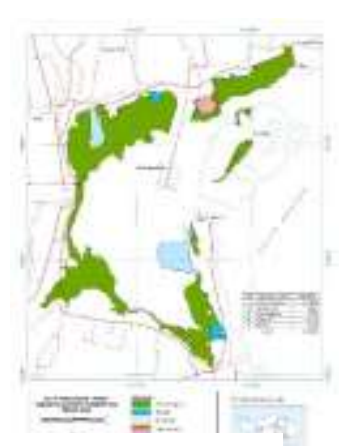

Tahun 2006

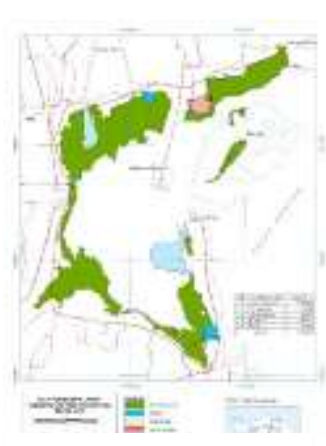

Tahun 2008

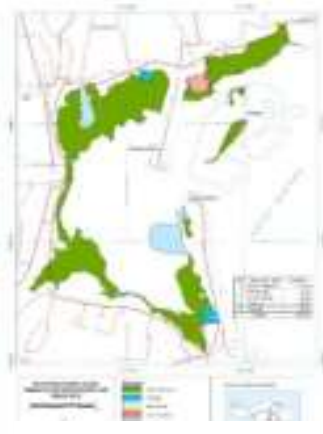

Tahun 2010

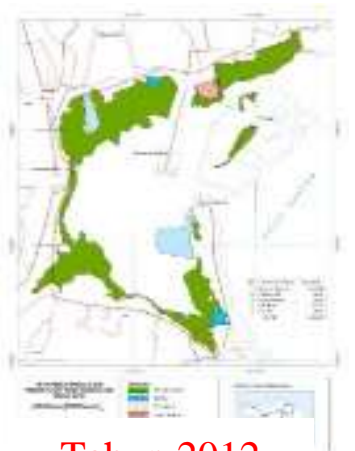

Tahun 2012

Gambar 1

Alih Fungsi Lahan Mangrove di Kawasan Tahura Ngurah Rai Tahun 2000 - 2012 Sumber: Badan Pemantapan Kawasan Hutan. 2018.

Hasil analisa citra satelit yang diolah Balai Pemantapan Kawasan Hutan (2018) pun menegaskan hal yang sama bahwa terjadi alih fungsi lahan hutan mangrove sebesar 29,76 ha dalam kurun waktu 12 tahun, yaitu dari tahun 2000 hingga 2012.Alih fungsi lahan hutan mangrove di Kawasan Tahura Ngurah Rai Bali terjadi mulai tahun 2004, dan murni disebabkan karena bertambahnya luas tutupan tambak sebesar 0,81 ha. Di tahun 2008, bertambahnya luas tutupan tambak merupakan faktor pertambahan terbesar dari alih fungsi lahan hutan mangrove.Di tahun 2010, bertambahnya luas tutupan tubuh air merupakan faktor pertambahan luas terbesar. Sedangkan di tahun 2012, bertambahnya luas pemukiman merupakan faktor terbesar dalam alih fungsi lahan hutan mangrove di Kawasan Tahura Ngurah Rai Bali.

\subsection{Persepsi Masyarakat Sekitar Mangrove Terhadap Pelestarian Mangrove di Kawasan Tahura Ngurah Rai Bali}

Persepsi merupakan penilaian seseorang terhadap objek atau peristiwa yang menjadi pusat perhatiannya. Hasil penilaian ini akan mempengaruhi baik tidaknya perilaku seseorang tersebut terhadap objek atau peristiwa itu. Setiap individu dapat Tabel 6. Total Nilai Persepsi Masyarakat Terh memiliki persepsi lingkungan yang berbeda terhadap objek yang sama karena itu tergantung pada latar belakang yang dimiliki.Persepsi masyarakat sekitar hutan mangrove dipengaruhi oleh pengalamanpengalaman, pengamatan-pengamatan, serta karakteristik yang mereka miliki selama ini.

Kajian mendalam tentang persepsi dan perilaku masyarakat sekitar mangrove terhadap pelestarian hutan mangrove di Kawasan Tahura Ngurah Rai Balidimulai dari pembahasan karakteristik responden, persepsi, dan ditutup dengan perilaku. Deskripsi mengenai karakteristik responden penelitian, antara lain meliputi:karakter masyarakat menurut kelompok usia,karakter masyarakat menurut jenis kelamin,karakteristik menurut tingkat pendidikan, karakteristik masyarakat menurut mata pencaharian, karakteristik masyarakat menurut pendapatan,dan karakteristik menurut status kepemilikan rumah.

Tingkat persepsi masyarakat sekitar mangrove terhadap pelestarian mangrove di Kawasan Tahura Ngurah Rai Bali meliputi persepsi terhadap fungsi, masalah, dan pelestarian mangrove. Dari hasil wawancara, diperoleh nilai persepsi fungsi mangrove ditampilkan dalam Tabel 6.

\begin{tabular}{|c|c|c|c|c|c|c|}
\hline \multirow[t]{2}{*}{ Nomor Variabel } & \multicolumn{4}{|c|}{ Skor Jawaban } & \multirow[t]{2}{*}{ Nilai } & \multirow[t]{2}{*}{ Interpretasi } \\
\hline & 4 & 3 & 2 & 1 & & \\
\hline 1 & 152 & 18 & 0 & 0 & 3,86 & Sangat baik \\
\hline 2 & 88 & 66 & 0 & 0 & 3,50 & Sangat baik \\
\hline 3 & 156 & 15 & 0 & 0 & 3,88 & Sangat baik \\
\hline 4 & 32 & 16 & 66 & 6 & 2,72 & Baik \\
\hline 5 & 24 & 30 & 50 & 13 & 2,66 & Baik \\
\hline 6 & 100 & 18 & 0 & 13 & 2,98 & Baik \\
\hline Nilai rata-rata & & & & & 3,27 & Sangat baik \\
\hline
\end{tabular}


Nilai rata-rata persepsi masyarakat terhadap fungsi mangrove adalah 3,27. Baiknya persepsi masyarakat akan fungsi mangrove merupakan modal positif untuk pelestarian hutan mangrove di Kawasan Tahura Ngurah Rai Bali. Keberhasilan pengelolaan hutan mangrove bergantung pada cara pandang atau persepsi masyarakat tentang hutan mangrove.,dan persepsi masyarakat terhadap masalah mangrove, diperoleh nilai rata-rata 3,42 yang ditampilkan dalam Tabel 7.

Tabel 7. Total Nilai Persepsi Masyarakat Terhadap Masalah Mangrove

\begin{tabular}{|c|c|c|c|c|c|c|}
\hline \multirow[t]{2}{*}{ Nomor Variabel } & \multicolumn{4}{|c|}{ Skor Jawaban } & \multirow[t]{2}{*}{ Nilai } & \multirow[t]{2}{*}{ Interpretasi } \\
\hline & & & & & & \\
\hline 1 & 112 & 0 & 10 & 10 & 3,00 & Baik \\
\hline 2 & 136 & 15 & 0 & 5 & 3,55 & Sangat baik \\
\hline 3 & 72 & 36 & 0 & 36 & 2,73 & Baik \\
\hline 4 & 132 & 33 & 0 & 0 & 3,75 & Sangat baik \\
\hline 5 & 176 & 0 & 0 & 0 & 4,00 & Sangat baik \\
\hline 6 & 132 & 0 & 22 & 0 & 3,50 & Sangat baik \\
\hline Nilai rata-rata & & & & & 3,42 & Sangat baik \\
\hline
\end{tabular}

Nilai rata-rata 3,42 pada Tabel 7 menandakan persepsi masyarakat terhadap masalah mangrove sangat baik. Masyarakat mengetahui faktor internal yang menjadi kelemahan adalah banyaknya sampah dan lumpur, serta adanya sedimentasi di Tahura Ngurah Rai bagian hilir, sedangkan faktor eksternal yang menjadi ancaman pengelolaan adalah adanya kepentingan pihak-pihak tertentu yang cenderung mengurangi keberadaan dan kelestarian hutan mangrove, pembuangan sampah di daerah hulu, dan pembangunan infrastruktur di sekitarnya.Dari hasil wawancara tentang persepsi masyarakat sekitar hutan mangrove terhadap masalah mangrove, diperoleh nilai rata-rata 3,67 , ditampilkan dalam Tabel 8.

Tabel 8. Total Nilai Persepsi Masyarakat Terhadap Pelestarian Mangrove

\begin{tabular}{|c|c|c|c|c|c|c|}
\hline \multirow[t]{2}{*}{ Nomor Variabel } & \multicolumn{4}{|c|}{ Skor Jawaban } & \multirow[t]{2}{*}{ Nilai } & \multirow[t]{2}{*}{ Interpretasi } \\
\hline & 4 & 3 & 2 & 1 & & \\
\hline 1 & 176 & 0 & 0 & 0 & 4,00 & Sangat baik \\
\hline 2 & 176 & 0 & 0 & 0 & 4,00 & Sangat baik \\
\hline 3 & 160 & 0 & 0 & 4 & 3,73 & Sangat baik \\
\hline 4 & 112 & 0 & 10 & 11 & 3,02 & Baik \\
\hline 5 & 136 & 0 & 10 & 5 & 3,43 & Sangat baik \\
\hline 6 & 160 & 0 & 8 & 0 & 3,82 & Sangat baik \\
\hline Nilai rata-rata & & & & & 3,67 & Sangat baik \\
\hline
\end{tabular}

Nilai rata-rata persepsi masyarakat sebesar 3,45 kategori sangat baik dari masingmasing sub sebagai berikut.

1. Persepsi masyarakat terhadap fungsi hutan mangrove $=3,27$.

2. Persepsi masyarakat terhadap masalah hutan mangrove $=3,42$.

3. Persepsi masyarakat terhadap pelestarian hutan mangrove $=3,67$.

Hasil ini menyiratkan bahwa masyarakat setempat menyadari pelestarian mangrove sangat mungkin dilakukan; pelestarian mangrove ini pun memerlukan keterlibatan masyarakat. Persepsi yang sangat baik ini tercipta oleh karena pendidikan yang dienyam masyarakat. Dalam pendidikan yang mereka enyam baik tamatan SD, SMP, ataupun SMA; mereka mendapatkan materi pembelajaran tentang mangrove dan bagaimana peranan vitalnya di pesisir sebuah pulau. Selain itu, persepsi yang sangat baik inipun terjadi akibat adanya sosialisasi 
peraturan adat yang berlaku di lokasi tempat tinggal masyarakat yang berdekatan dengan hutan mangrove.

\subsection{Perilaku Masyarakat Sekitar Mangrove Terhadap Pelestarian Mangrove di Kawasan Tahura Ngurah Rai Bali}

Dari hasil wawancara enam pertanyaan tentang perilaku masyarakat terhadap keberadaan mangrove, diperoleh nilai ratarata 1,84 yang menandakan perilaku masyarakat terhadap keberadaan mangrove termasuk kategori buruk. Total nilai perilaku masyarakat terhadap keberadaan mangrove ditampilkan dalam Tabel 9.

Tabel 9. Total Nilai Perilaku Masyarakat Terhadap Keberadaan Mangrove

\begin{tabular}{|c|c|c|c|c|c|c|}
\hline \multirow[t]{2}{*}{ Nomor Variabel } & \multicolumn{4}{|c|}{ Skor Jawaban } & \multirow[t]{2}{*}{ Nilai } & \multirow[t]{2}{*}{ Interpretasi } \\
\hline & 4 & 3 & 2 & 1 & & \\
\hline 1 & 16 & 0 & 0 & 40 & 1,27 & Sangat buruk \\
\hline 2 & 16 & 0 & 0 & 40 & 1,27 & Sangat buruk \\
\hline 3 & 16 & 0 & 0 & 40 & 1,27 & Sangat buruk \\
\hline 4 & 16 & 0 & 8 & 36 & 1,54 & Sangat buruk \\
\hline 5 & 144 & 0 & 8 & 4 & 3,55 & Sangat baik \\
\hline 6 & 60 & 0 & 8 & 25 & 2,11 & Buruk \\
\hline \multicolumn{5}{|c|}{ Nilai rata-rata } & 1,84 & Buruk \\
\hline
\end{tabular}

Dari hasil persentase disimpulkan bahwa walaupun masyarakat setempat menyadari bahwa mangrove berfungsi sangat vital sebagai penopang kehidupan masyarakat namun perilaku masyarakat terhadap keberadaan mangrove termasuk dalam kategori kurang baik. Masyarakat mengajak keluarga dan rekan berekreasi ke hutan mangrove, namun tanpa penjelasan fungsi dan manfaat mangrove itu sendiri. Sebagian masyarakat masih membuang sampah dan hajat di sekitar hutan mangrove, membangun pemukiman dengan menebang mangrove, tidak aktif ngayahmembersihan sampah yang datang dari hulu di sekitar mangrove dan mengontrol pertumbuhan mangrove-mangrove yang ada, bahkan mencaritau fungsi, pemanfaatan, dan pengolahan mangrove secara swadaya.

Hanya sebagian masyarakat yang menyadari pentingnya ngayah bagi lingkungan sekitar, seperti yang terjadi di
Desa Tuban. Tiap akhir minggu, sebagian masyarakat meluangkan waktunya untuk membersihkan sekitar mangrove dari sampahsampah kiriman, memasang rangkaian botolbotol bekas yang mampu menahan aliran sampah, mengontrol endapan yang terjadi, dan melakukan pembibitan mangrove. Di situasi inilah, peranan peraturan desa adat, yang melibatkan dan mengontrol masyarakat setempat dalam pelestarian mangrove.

Di sisi lain, nilai rata-rata perilaku masyarakat terhadap manfaat ekonomi mangrove termasuk dalam kategori baik. Baiknya perilaku masyarakat ini tercipta dari pengalaman-pengalaman mereka akan hasil ekonomi yang didapat dari pengelolaan mangrove. Nilai rata-rata perilaku masyarakat terhadap pemanfaatan mangrove dalam bidang ekonomi, ditampilkan dalam Tabel 10.

Tabel 10.Total Nilai Perilaku Masyarakat Terhadap Manfaat Ekonomi Mangrove

\begin{tabular}{|c|c|c|c|c|c|c|}
\hline \multirow[t]{2}{*}{ Nomor Variabel } & \multicolumn{4}{|c|}{ Skor Jawaban } & \multirow[t]{2}{*}{ Nilai } & \multirow[t]{2}{*}{ Interpretasi } \\
\hline & 4 & 3 & 2 & 1 & & \\
\hline 1 & 116 & 0 & 0 & 15 & 2,97 & Baik \\
\hline 2 & 84 & 0 & 0 & 23 & 2,43 & Buruk \\
\hline 3 & 84 & 0 & 0 & 23 & 2,43 & Buruk \\
\hline 4 & 116 & 0 & 0 & 15 & 2,97 & Baik \\
\hline 5 & 116 & 0 & 0 & 15 & 2,97 & Baik \\
\hline 6 & 116 & 0 & 0 & 15 & 2,97 & Baik \\
\hline \multicolumn{5}{|c|}{ Nilai rata-rata } & 2,79 & Baik \\
\hline
\end{tabular}


Dari tabel di atas disimpulkan bahwa sebagian besar masyarakat setempat pernah mengambil manfaat dari mangrove, baik bagian dari tumbuhan, biota, maupun menjual paket wisata mangrove. Sebagian besar masyarakat pun pernah mengikuti penyuluhan tentang pengolahan mangrove, bergabung dalam kelompok pengolahan, dan mendapatkan manfaat dari mangrove.Dari hasil wawancara, diperoleh nilai perilaku masyarakat yang beragam. Nilai rata-rata perilaku masyarakat terhadap keberadaan mangrove ditampilkan dalam Tabel 11.

Tabel 11. Total Nilai Perilaku Masyarakat Terhadap Pengetahuan Tentang Mangrove

\begin{tabular}{|c|c|c|c|c|c|c|}
\hline \multirow[t]{2}{*}{ Nomor Variabel } & \multicolumn{4}{|c|}{ Skor Jawaban } & \multirow[t]{2}{*}{ Nilai } & \multirow[t]{2}{*}{ Interpretasi } \\
\hline & 4 & 3 & 2 & 1 & & \\
\hline 1 & 76 & 0 & 0 & 25 & 2,29 & Buruk \\
\hline 2 & 76 & 0 & 0 & 25 & 2,29 & Buruk \\
\hline 3 & 176 & 0 & 0 & 0 & 4,00 & Sangat baik \\
\hline 4 & 156 & 0 & 0 & 5 & 3,66 & Sangat baik \\
\hline 5 & 156 & 0 & 0 & 5 & 3,66 & Sangat baik \\
\hline 6 & 20 & 0 & 0 & 39 & 1,34 & Sangat buruk \\
\hline \multicolumn{5}{|c|}{ Nilai rata-rata } & 2,87 & Baik \\
\hline
\end{tabular}

Dari Tabel 11 di atas, terlihat bahwa sebagian besar masyarakat belum memiliki minat baca, termasuk minat baca tentang mangrove; pengetahuan tentang mangrove lebih banyak direkam dalam bentuk visual. Bentuk visual bisa berupa program acara di televisi ataupun sosialisasi-sosialisasi yang ada. Di sisi lain, masyarakat setempat pun mengetahui peraturan tentang mangrove di Kawasan Tahura Ngurah Rai Bali dan peraturan adat yang berlaku.

Nilai rata-rata perilaku masyarakat sebesar 2,08 kategori buruk dari masingmasing sub sebagai berikut.

1. Perilaku masyarakat terhadap keberadaan hutan mangrove $=1,84$.

2. Perilaku masyarakat terhadap manfaat ekonomis mangrove $=2,79$.

3. Perilaku masyarakat terhadap pengetahuan tentang mangrove $=2,87$.

Bila nilai rata-rata perilaku dibandingkan dengan nilai rata-rata persepsi masyarakat, bisa disimpulkan bahwa walaupun masyarakat setempat menyadari pelestarian mangrove sangat diperlukan dengan keterlibatan masyarakat, namun masyarakat tidak mengimpletasikan pelestarian mangrove tersebut secara maksimal di keseharian mereka. Hal ini terjadi karena sebagian besar mata pencaharian masyarakat yang tidak berhubungan dengan mangrove sehingga masyarakat kurang peka terhadap hutan mangrove di sekitar mereka. Prioritas hidup masyarakat yang cenderung terfokus pada pertumbuhan ekonomi tanpa mengindahkan dampak lingkungan, juga menjadi andil dalam buruknya perilaku masyarakat terhadap pelestarian hutan mangrove di Kawasan Tahura Ngurah Rai Bali.

\section{SIMPULAN DAN SARAN}

\subsection{Simpulan}

Dari hasil dan pembahasan penelitian yang telah dilaksanakan, dapat disimpulkan hal-hal sebagai berikut.

1. Secara keseluruhan, bentuk alih fungsi lahan mangrove di Kawasan Tahura Ngurah Rai Bali adalah pemukiman, lahan terbuka, tubuh air, dan tambak. Tahun 2004 dan tahun 2008, faktor terbesar dari alih fungsi lahan mangrove disebabkan bertambahnya tambak seluas 0,81 ha dan 9,9 ha. Tahun 2010, faktor terbesar dari alih fungsi lahan mangrove disebabkan bertambahnya luas tutupan tubuh air sebesar 6,27 ha. Sedangkan tahun 2012, faktor terbesar dari alih fungsi lahan mangrove disebabkan bertambahnya luas pemukiman sebesar 3,93 ha. Alih fungsi lahan mangrove yang berlangsung terus menerus berdampak pada rendahnya 
keanekaragaman spesies mangrove dan terganggunya kondisi lingkungan mangrove yang berdampak pada masyarakat sekitar.

2. Tingkat persepsi masyarakat sekitar mangrove terhadap pelestarian mangrove di Kawasan Tahura Ngurah Rai Bali dikategorikan sangat baik. Persepsi sangat baik ini timbul karena dukungan karakter masyarakat, antara lain: tingkat pendidikan, mata pencaharian, dan status ekonomi menengah ke atas. Persepsi sangat baik ini sangat membantu dan mempermudah pelaksanaan program atau kegiatan yang dilakukan Pemerintah maupun pemakrasa dari masyarakat.

3. Tingkat perilaku masyarakat sekitar mangrove terhadap pelestarian mangrove di Kawasan Tahura Ngurah Rai Bali dikategorikan buruk. Dampak dari kurang baiknya perilaku masyarakat sekitar mangrove terhadap pelestarian mangrove di Kawasan Tahura Ngurah Rai Bali, antara lain: berkurangnya keanekaragaman spesies mangrove dan terjadinya gangguan pada kondisi lingkungan mangrove.

\subsection{Saran}

Beberapa saran yang dapat diajukan Peneliti dalam penyusunan tesis mengenai Persepsi dan Perilaku Masyarakat Sekitar Mangrove Terhadap Pelestarian Mangrove di Kawasan Tahura Ngurah Rai Bali ini adalah sebagai berikut.

1. Perlunya ketegasan Pemerintah untuk menjalankan peraturan-peraturan hutan mangrove yang ada dan giat mengenalkan keanekaragaman mangrove pada masyarakat lewat sosialisasi ke sekolahsekolah maupun di tingkat masyarakat. Sosialisasi yang dikemas menarik dilanjutkan dengan penanaman dan pemeliharaan bersama secara berkesinambungan.

2. Persepsi masyarakat yang sangat baik terhadap pelestarian mangrove perlu terus dipupuk dan dikembangkan. Pemupukan persepsi masyarakat tidak hanya dengan memberikan ilmu pengetahuan, namun juga dengan pengalaman pelestarian mangrove, yang membuat masyarakat lebih tertarik dan antusias.

3. Pihak Pemerintah dapat menunjuk kelurahan atau desa yang berhasil dalam pelestarian mangroveseperti Desa Tuban sebagai percontohan, sehingga memacu kelurahan atau desa lainnya di Kawasan Tahura Ngurah Rai Bali. Disamping itu, diperlukan pemberdayaan masyarakat melalui penyuluhan tentang pelestarian dan manfaat mangrove, pendampingan tenaga-tenaga terampil, dan modal. Diperlukan pula ketegasan Pemerintah dan adat dalam mengaplikasikan peraturan pelestarian mangrove. Ketiga cara ini memberi ruang bagi masyarakat untuk mengemukakan ide-ide baru dan sinergi untuk terciptanya perilaku pelestarian mangrove yang lebih baik.

\section{DAFTAR PUSTAKA}

Bali Post. 2017. Tahura Ngurah Rai Paling Terancam. $26 \quad$ April 2017. www.balipost.com.

Buwono, Y. R., Susanti, D. D., Arsana, J., Indrawan, E., Wijaya, K., dkk. 2014. Identifikasi Mangrove di Taman Hutan Raya Ngurah Rai. Laporan Praktikum Mata Kuliah Ekologi dan Ilmu Lingkungan. Program Studi Magister Ilmu Lingkungan. Universitas Udayana.

Campbell, A. dan Brown, B. 2015. Indonesia's Vast Mangrves are Treasure Worth Saving. Charles Darwin University.

Champion D. J. 1981. Basic Statistic for Social Research. Second Edition. Editorial: MacMillan Publishing Company. New York.

Dinas Kehutanan Provinsi Bali. 2014. Kebijakan Pembangunan Kehutanan Provinsi Bali dalam Mendukung Pelestarian Mangrove di Provinsi Bali. Presentasi Dinas Kehutanan Provinsi Bali di Klungkung. 4 Maret 2014.

Haminuddin. 2014. Ecological and Economic Evaluation of Mangrove Forest Resource: Case Study in the Ngurah Rai Forest Park Bali. Hirosima University. 
Lugina, Alviya, Indratik, dan Pribadi. 2017. Strategi Keberlajutan Pengelolaan Hutan Mangrove di Tahura Ngurah Rai bali. Pusat Penelitian dan Pengembangan Sosial, Ekonomi, Kebijakan, dan Perubahan Iklim.

FAO. 2007. The World's Mangroves $1980-$ 2005. Forest Resources Assesment Working Paper. No 153. Rome: Food and Agriculture Organization of United Nations.

Muhaimin, A. 2016. Persepsi Masyarakat Terhadap Hutan Mangrove di Desa Margasar Kabupaten Lampung Timur. Departemen Konservasi Sumberdaya Institut Pertanian Bogor.

Peraturan Pemerintah Republik Indonesia Nomor 28 Tahun 2011 tentang Kawasan Suaka Alam dan Kawasan Pelestarian Alam.

Pradnyana, I. N. B., Arnawa, I. K., Tamba, I. M. 2015. Faktor-faktor yang Mempengaruhi Kunjungan Wisatawan di Taman Hutan Raya Ngurah Rai. Jurnal Pertanian Berbasis Keseimbangan Ekosistem.

Setiawan, H., Purwanti, R., Garsetiasih. 2017. Persepsi dan Sikap Masyarakat Terhadap Konservasi Ekosistem Mangrove di Pulau Tanakeke Sulawesi Selatan. Jurnal Penelitian Sosial dan Ekonomi Kehutanan. Vol. 14. No. 1. 57 -70 .

Subhan, M. 2014. Analisis Tingkat Kerusakan dan Strategi Pengelolaan Mangrove di Kawasan Suaka Perikanan Gili Ranggo Teluk Seriwe Kabupaten Lombok Timur Nusa Tenggara Barat. Program Magister Ilmu Lingkungan. Universitas Udayana.

Supriyanti, E., Azizah, R., dan Pramesthi, C. 2017. Daya Serap Mangrove Rhizophora sp. Terhadap Logam Berat Timbal $(\mathrm{Pb})$ di Perairan Mangrove Park, Pekalogan. Jurnal Kelautan Tropis. Vol. 20. No. 1. $16-24$. 